\title{
Oral Squamous Cell Papilloma: A Case Report and Review
}

\author{
Athul Santhosh and Sreelakshmi N Nair* \\ Department of Oral medicine and radiology \& Private practitioner, Santhosh Dental Clinic, India
}

Submission: May 21, 2018; Published: May 31, 2018

*Corresponding author: Sreelakshmi N Nair, Oral medicine and radiology, Private practitioner, Santhosh Dental Clinic, Suhas Tower, Kanhangad, Kasargod Dist, Kerala, India, Tel: +917829030464; Email: sreelakshminnair@gmail.com

\section{Abstract}

Squamous papillomas are common lesions of the oral mucosa related to human papilloma virus even though the controversy regarding its pathogenesis still exists. It most often occurs on the tongue and the hard palate. It is important to diagnose it correctly as it may mimic malignant lesions. Here we present a case of oral squamous cell papilloma and its review.

Keywords: Papilloma virus; Tongue; Malignant lesion

\section{Case Report}

A 75 year male patient reported to the clinic with a chief complaint of a growth over the right side of the tongue since 1 year. The growth was associated with a dull pain and a mild discomfort in speech and deglutition. Initially it was small in size later it grew larger and reduced in its size after undergoing extraction of few teeth nearer to it.

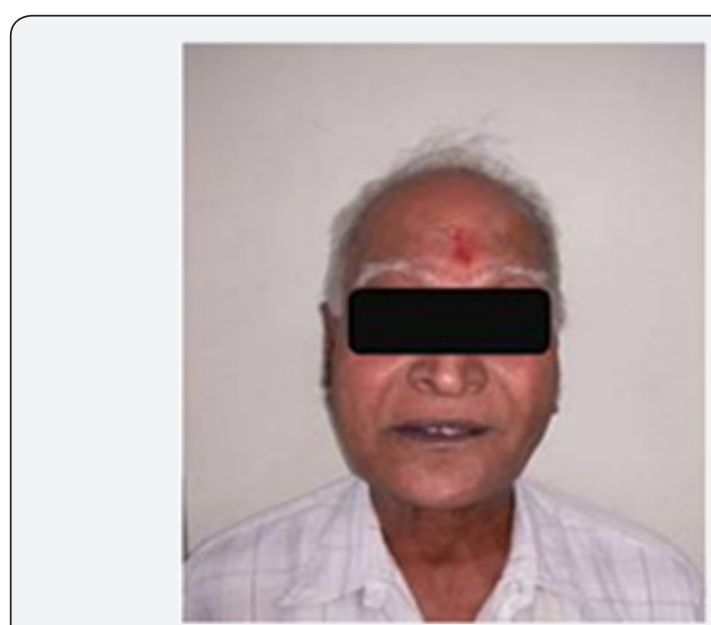

Figure 1: Showing the patient profile.

On extra oral examination, there was reduced vertical dimension of the face (Figure 1). Intraoral examination revealed an exophytic tissue growth in relation to right lateral border of tongue of size $2 * 2 \mathrm{~cm}$, extending over to the ventral surface of the tongue. Surface of the tongue appeared fissured and lobulated. A linear white keratotic area was seen over the right lateral and ventral aspect of the tongue (Figure 2). On palpation, slight tenderness was present. Base appeared indurated and firm in consistency. The white keratotic area was non scrapable and non tender. After clinical examination, a provisional diagnosis of malignant lesion of the tongue was given with a TNM staging of T1N0M0.

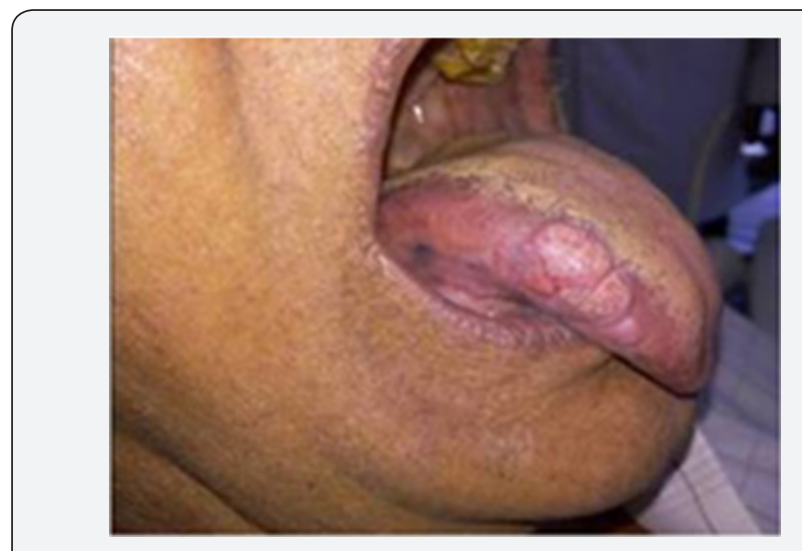

Figure 2: Showing the intraoral examination: Exophytic growth on the right lateral border of the tongue.

Toluidine blue staining was done and the lesion did not take up the stain (Figure 3). The patient was referred to an oral surgeon for excisional biopsy, where the histopathological analysis revealed multiple finger like projections of stratified squamous epithelium exhibiting hyperkeratosis and keratin plugging. The underlying connective tissue entrapped within the papillary projections showed chronic inflammatory infiltrate. Based on the clinical and histopathological report, the final diagnosis given was Squamous Papilloma of the tongue. 


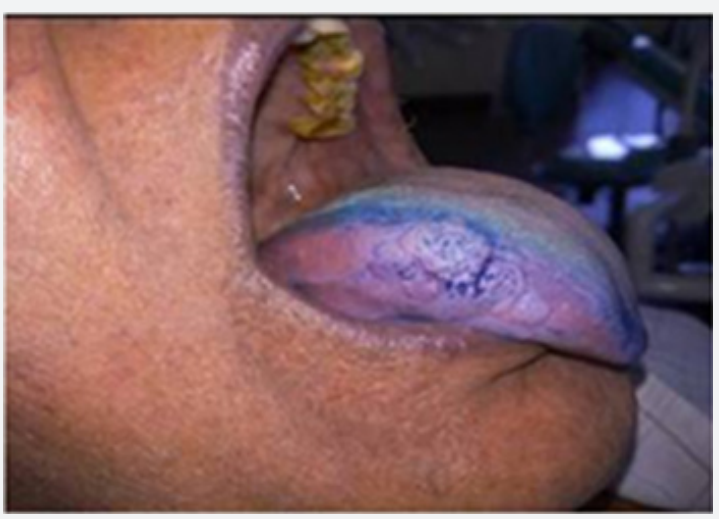

Figure 3: Showing the picture after toluidine blue staining.

\section{Discussion}

\section{Incidence}

Among the papillary lesions of oral mucosa, it is the commonest. It is estimated that 4 in 1000 persons exhibit oral squamous papilloma. It is usually reported in the age group of 30-50 years, unlike our case which was seen in a 65 year old male patient. There is equal sex incidence, even though few studies show slight male predilection [1]. The whitish color of the lesions indicates the thickness of the cornified layer which was seen in our case too [2].

It is caused by Human Papillomavirus (HPV) types 6 and 11 (HPV 6 and HPV 11) which is less virulent and with low infectivity rate. The pathogenesis is that, the double stranded viral DNA integrates with the host DNA leading to the development of papilloma [3].

The lesion often presents as a well circumscribed, solitary exophytic growth with a, roughened or wart like surface. The surface either has numerous small finger-like projections or may be blunted. It is seen almost always as a pedunculated lesion but can be sessile occasionally. It is mostly painless. Depending on the thickness of keratinization, the appears white or pink.
Sometimes the surface appears reddened due to trauma. The lesion often measures from a few millimetre to less than $1 \mathrm{~cm}$ in diameter but sometimes large lesions can be seen [4].

Electron microscopic analysis is preferred over conventional biopsy. The other methods of detection are in situ hybridization, immunohistochemistry and polymerase chain reaction (PCR) technique [5]. It is lined by well ordered stratified squamous epithelium. There is perinuclear cytoplasmic vacuolisation of spinous cells which are surrounded by optically clear zone forming perinuclear pale halos and pyknosis. The connective tissue is fibrovascular in nature with chronic inflammatory cell infiltration [6].

The preferred treatment is surgical excision. Either routine excision or laser ablation can be used. Other treatment modalities include electrocautery, cryosurgery, and intralesional injections of inter-feron. Recurrence is not common, except in patients infected with human immunodeficiency virus (HIV) [7].

\section{References}

1. Neville BW, Damm DD, Allen CM, BouquotJE (2004) Oral \& maxillofacial pathology. ( $\left.2^{\text {nd }} e d n\right)$, pp. 304-305.

2. Carneiro TE, Marinho SA, Verli FD, Mesquita AT, Lima NL, et al. (2009) Oral squamous papilloma: clinical, histologic and immunohistochemical analyses. J Oral Sci 51(3): 367-372.

3. Syrjänen S (2003) Human papillomavirus infections and oral tumors. Med Microbiol Immunol 192(3): 123-128.

4. Rajendran R, Sivapathasundaram B (2009) Benign and malignant tumors of oral cavity. Shafer's textbook of Oral Pathology, $6^{\text {th }}$ Edn, Elsevier, Noida, New Delhi, India.

5. Satheesh Kumar K, Premlal KR, Sivaramakrishnan M, Aroumougam A (2017) Oral Squamous Papilloma. Journal of Scientific Dentistry 7(1): 46-49.

6. Bao Z, Yang X, Shi L, Feng J, Liu W, et al. (2012) Clinicopathologic features of oral squamous papilloma and papillary squamous cell carcinoma: a study of 197 patients from eastern China. Ann Diagn Pathol 16(6): 454-458.

7. Marx RE, Stern D (2003) Oral and Maxillofacial Pathology: A Rationale for Treatment. Quintessence Publishing, Hanover Park, Illinois, USA.

\section{Your next submission with Juniper Publishers will reach you the below assets}

- Quality Editorial service

- Swift Peer Review

- Reprints availability

- E-prints Service

- Manuscript Podcast for convenient understanding

- Global attainment for your research

- Manuscript accessibility in different formats ( Pdf, E-pub, Full Text, Audio)

- Unceasing customer service

Track the below URL for one-step submission https://juniperpublishers.com/online-submission.php 